Institute of Public Health of Vojvodina, Novi Sad ${ }^{1}$ University of Novi Sad, Faculty of Medicine ${ }^{2}$

Clinical Center of Vojvodina, Novi Sad

Clinic of Infectious Disease ${ }^{3}$
Professional article

Stručni članak

UDK 616.988:595.771]-036.22 i 616.988:595.771]-07/-08

DOI: $10.2298 / \mathrm{MPNS} 1504122 \mathrm{H}$

\title{
CHIKUNGUNYA - A SERIOUS THREAT FOR PUBLIC HEALTH
}

\author{
ČIKUNGUNIJA VIRUS - OZBILJNA PRETNJA ZA JAVNO ZDRAVLJE
Ivana B. HRNJAKOVIĆ CVJETKOVIĆ ${ }^{1,2}$, Dejan CVJETKOVIĆ ${ }^{2,3}$, Aleksandra PATIĆ1,2, Nataša NIKOLIĆ ${ }^{1,2}$, Sandra STEFAN MIKIĆ ${ }^{2,3}$ and Vesna MILOŠEVIĆ ${ }^{1,2}$

\begin{abstract}
Summary
Introduction. Chikungunya is a contagious disease caused by Chikungunya virus, an arbovirus from the Togaviridae family. This infection is mostly spread by mosquitoes from the genus Aedes, especially Aedes albopictus, which have spread from Asia to America and Europe including some countries surrounding Serbia. Epidemiologic Features. The outbreak of epidemics has been reported in Philippines, Sumatra, Java, Indonesia, West Africa region (from Senegal to Cameroon), Congo, Nigeria, Angola, Uganda, Guinea, Malawi, Central African Republic, Burundi, South Africa and India. At the beginning of the 21st century, large outbreaks were recorded on the island of Réunion. During 2006, 1.400 .000 cases of chikungunya infection were recorded in India. Local transmission of infection in continental Europe was reported from Northeast Italy (254 suspected and 78 laboratory confirmed cases in Emilia-Romagna region) and France (two cases in 2010). From December 2013 to June 2014, 5.294 confirmed cases and more than 180.000 suspected cases of chikungunya were reported in the Caribbean. Clinical Findings. The disease presents suddenly with fever, rush and arthralgia. In general, chikungunya is a mild self - limited disease. Less often, it may be presented with signs of meningoencephalitis or fulminant hepatitis, sometimes with fatal outcome. Conclusion. Fast developing international traffic and booming tourism as well as the vector spreading from its homeland make chikungunya a real threat to our country.

Key words: Chikungunya Fever; Chikungunya virus; Serbia; Signs and Symptoms; Diagnosis; Epidemiology; Risk Factors; Public Health; Aedes
\end{abstract}

\section{Introduction}

Chikungunya is a disease of viral origin, and until recently it has been geographically connected with tropical areas of Africa, Southeast Asia and

\footnotetext{
Acknowledgment:

The article was written within the projects TR31084 and TR43007 financed by the Ministry of Education and Science of the Republic of Serbia and the project 114-451-2142/2001-01 (2011-2014) of the Secretariat for Science and Technological Development of the Autonomous Province of Vojvodina.
}

\begin{abstract}
Sažetak
Uvod. Čikungunija je zarazna bolest izazvana arbovirusom čikungunija iz porodice Togaviridae. U širenju infekcije presudna je uloga vektora komarca Aedes albopictus koji se iz postojbine Azije proširio i na Ameriku i Evropu, uključujući i zemlje u našem okruženju. Epidemiološke karakteristike. Epidemijska pojava bolesti registrovana je na Filipinima, Sumatri, Javi, Timoru, u Indoneziji, Zapadnoj Africi od Senegala do Kameruna, Kongu, Nigeriji, Angoli, Ugandi, Gvineji, Malaviju, Centralnoj Afričkoj Republici, Burundiju, Južnoj Africi i Indiji. Početkom 21. veka registrovane su velike epidemije na ostrvu Reinion (Le Réunion). U Indiji je registrovano 1400000 slučajeva čikungunije tokom 2006. godine. U nekoliko evropskih zemalja registrovani su importovani slučajevi ovoga oboljenja. U severoistočnoj Italiji u oblasti EmilijaRomanja registrovana je prva epidemija u umerenom klimatskom pojasu sa 254 suspektna i 78 laboratorijski potvrđenih slučajeva. Dva slučaja lokalne transmisije registrovana su i u Francuskoj 2010. godine. Od decembra 2013. do juna 2014. godine, 5294 potvrđena slučaja i 180000 verovatnih slučajeva čikungunje registrovano je na Karibima. Klinički nalazi. Bolest se klinički manifestuje akutnim početkom s groznicom, osipom po koži i artralgijama. Generalno, čikungunja je blaga bolest koja prolazi sama, bez komplikacija. Registrovani su i slučajevi meningoencefalitisa i fulminantnog hepatitisa. Smrtni ishod je redak. Zaključak. Sve intenzivniji saobraćaj i razvoj turizma, uz širenje vektora iz njegove postojbine, čine ovu bolest realnom pretnjom i za našu zemlju.

Ključne reči: Čikungunija groznica; Čikungunija virus; Srbija; Znaci i simptomi; Dijagnoza; Epidemiologija; Faktori rizika; Javno zdravlje; Komarac Aedes albopictus
\end{abstract}

the region of the Indian Ocean [1]. Chikungunya presents with an abrupt onset, fever, skin rash and heavy arthralgia. The term originates from the word which in Swahili and Maconde language means "the one that is folded". Chikungunya has become the subject of increased interest at the beginning of the 21 st century due to a number of large outbreaks with a lot of severe clinical forms of disease in India and on the islands in the Indian Ocean. Until recently, there were no outbreaks of chikungunya in Europe and America. However, an outbreak of chikungunya in Northeast Italy, expansion of 


\author{
Abbreviations \\ RT-PCR - Real-time polymerase chain reaction \\ ELISA - enzyme linked immunosorbent assay \\ IgM - immunoglobulin class M \\ IgG - immunoglobulin class $\mathrm{G}$ \\ MRC-5 - human lung fibroblast cell cuture \\ DNK - deoxyribonucleic acid \\ ECDC - European Centre for Disease Prevention and Control \\ USA - United States of America
}

chikungunya virus infection in the Caribbean and in South America in addition to fast international transportation and developed tourism requires from the Serbian health professionals to be aware of the possibility of professional exposure to chikungunya virus $[2,3]$. Chikungunya virus is an arbovirus, a member of the Alphavirus genus in the family Togaviridae, 60-70 nm in diameter, with icosahedral symmetry and single-stranded ribonucleic acid - positive genome of 11 - 12 kilobases. Nucleocapsid is enveloped by phospholipid layer with glycoprotein antigens E1 and E2 inserted onto this layer. Those glycoproteins play a role in virus adsorption to the cell membrane receptor; they are responsible for the production of neutralizing antibodies. According to antigenic structure, genus Alphavirus can be divided into 7 serocomplexes. Chikungunya virus belongs to antigenic complex IV (Semliki Forest complex). The virus was discovered in a serum sample of a patient in Tanzania in 1953. Since then, two viral lines have been registered: Central-SouthEast-African line and West-African line including Asian genotype [4].

\section{Epidemiologic Features}

The primates are the natural reservoir of chikungunya virus. The Aedes mosquitoes transmit this virus to humans. The Aedes aegypti and the Aedes albopictus are the vectors of infection in Africa and Asia [5, 6]. It is believed that the Aedes albopictus is transmitted from Asia to other continents by importing used tires contaminated with mosquito eggs. Due to remarkable adaptability to urban life conditions, the Aedes albopictus has settled Belgium, Bosnia, Croatia, France, Greece, the Netherlands, Spain, Switzerland as well as Central America, Brazil and the United States of America (USA) [7]. In addition to mutations in viral genome, which increase contagiousness of virus for Aedes albopic$t u s$, vector expansion represents main factors that contribute to spreading this virus worldwide [8].

In geographic areas where the reservoirs and the vectors are widely distributed and human population possesses protective immunity to a high degree, sporadic cases and small outbreaks occur. Massive outbreaks occur in population with no protective immunity. Epidemic appearance of disease was reported in the Philippines, Sumatra, Java, Timor, Indonesia, West Africa from Senegal to Cameroon, Congo, Nigeria, Angola, Uganda, Guinea, Malawi,
Central African Republic, Burundi, South Africa and India [9]. More than 1.400 .000 cases of chikungunya virus infection were recorded in India in 2006 [10]. Reunion, an island in the Indian ocean, was hit by a chikungunya outbreak in 2005; the estimated incidence of 40.000 cases per week was reached there in 2006 [11].

In the first decade of the 21st century, imported cases of chikungunya among passengers arriving from areas with a high incidence of chikungunya virus infection were reported in Europe and the USA. The appearance of imported cases in areas where the vectors are maintained concomitantly with the presence of specific climate features of environment creates the conditions for the occurrence of local autochthonous cases [12]. The first outbreak with autochthonous cases in Europe was recorded in Northeast Italy, Emilia-Romagna region, in July 2007 with a total of 254 suspected and 78 laboratory confirmed chikungunya cases [13]. Two autochthonous cases of chikungunya infection were recorded in southeastern part of France in 2010 [14]. The first autochthonous viral transmission in America was recorded on December 6, 2013, when two cases of chikungunya infection were confirmed in laboratory on Saint Martin island (located in the Caribbean). In the next few months, chikungunya infection spread across the majority of Caribbean islands and South America. More than 100.000 probable cases and 4.182 confirmed cases of disease were reported in June 2014 [15]. Experts from the European Center of Control and Prevention of Diseases have estimated that there is a considerable risk of disease spreading across the continental America where the Aedes aegypti is endemic, as well as to European continent where the Aedes albopictus exists and to the island of Madeira where there is a high risk to get infected by chikunguya virus. Two factors which contribute to virus spreading on the island of Madeira are the native presence of vector and appropriate climate features for its growth [3]. Is it a repetition of epidemiologic scenario already seen during the expansion of the West Nile virus that has been only an exotic member of arboviruses for a long time which has subsequently spread and become endemic in America and $\mathrm{Eu}-$ rope provoking several outbreaks, two of which occurred in Serbia in 2012 and 2013 [16].

\section{Clinical Findings}

Incubation period ranges from 1 to 12 days (2-4 days on average). Asymptomatic infection may occur, but its incidence is still unknown. Clinically manifested disease begins abruptly with fever, headache, back pains, myalgia and arthralgia. The most common sites of pains are ankles, wrists and interphalangeal joints of hand; big joints may be involved less often. Skin rash is present in half of the cases. In adults, rash may be maculopapular, pruriginous and most dense on the thorax. In children, rash most often has bullous presentation, followed by 
crusting. Facial edema may appear as well as localized petechiae and gingival hemorrhages [17, 18]. The analysis of 504 patients in the outbreak on Reunion island showed that fever and arthralgias were present in all of them, as well as headache (70\%), myalgia $(60 \%)$ and rash (39\%). In the outbreak in Malaysia in 1998 , all of 51 patients were febrile, a half of them manifested rash, myalgia, headache and back pains, $78 \%$ of patients presented with small joint arthralgias, whereas $18 \%$ had large joint arthralgias. The patients' complaints resolved within 7-10 days except rigidity and arthralgias, which lasted for a longer period of time [19]. The main characteristic of chikungunya is the presence of recurrent arthralgia and arthritis, which persist in $73-80 \%$ of cases with serologic confirmation of disease. In one-third of cases the duration of arthralgia/arthritis is 4 months, whereas in $10 \%$ of cases it lasts from 3 to 5 years. Pathogenesis of joint manifestations is unclear. Radiographs of affected joints are normal, while biologic inflammatory markers are normal or show moderately elevated values [20].

Chikungunya is most often associated with favorable prognosis quoad vitam. During the outbreak of chikungunya on Reunion islands, 3.9\% of patients were admitted to hospital [21]. Meningoencephalitis cases from this outbreak confirm neurotropism of chikungunya virus. Those cases were recorded in the outbreak of chikungunya on Reunion islands at a rate of 1.7/1000 cases of chikungunya [21].

Infection of pregnant women is possible during the whole pregnancy. Transmission of infection during the first trimester of pregnancy may be ended by miscarriage. Viral transmission from the mother to her fetus usually occurs through maternal viremia during the delivery. Transplacental and perinatal transmission of infection was first described in relation to the outbreak on Reunion island. In 159 pregnant women with clinically manifested disease, etiology was confirmed by serologic testing or real-time polymerase chain reaction (RT-PCR). Out of 35 pregnant women who were ill at the time of delivery, 30 gave birth to an infected child. The disease in pregnant women is not more severe than in non-pregnant ones. Neonatal chikungunya is severe disease and clinically resembles neonatal dengue virus infection [9]. So far there has been no prospective study to examine the risk for embryopathies, fetopathies and late sequelae in infected children.

\section{Laboratory Diagnosis}

RT-PCR with reversal transcription performed on serum sample of patient is suitable to make the diagnosis early (the first week of disease) [3]. Among serologic tests, hemagglutination inhibition reaction, complement fixation test, fluorescent antibody test and enzyme linked immunosorbent assay (ELISA) could be applied. Immunoglobulin M (IgM) chikungunya antibodies can be proved as early as on the second day of disease and persist for 3 months. In all imported cases, $\operatorname{IgM}$ and $\operatorname{IgG}$ chikungunya antibodies were proved after the 5 th day since the onset of disease [22]. IgM antibodies persist for a number of years. Evaluation of serological results should not ignore cross-reactivity to dengue virus and o'nyong-nyong virus. The diagnosis can also be made either by virus isolation on suitable cell cultures or in mice. Cell cultures of mammals are suitable. The virus may be isolated by intracerebral inoculation into baby mice [4].

\section{Immunity and Vaccination}

After recovering from natural chikungunya virus infection, humans acquire solid immunity. There is no commercial vaccine for humans. However, studies on live vaccine developed in United States Army Medical Research Institute of Infectious Diseases were conducted until 2000; as vaccinia virus, the "15561" virus isolated in a Thai patient and then attenuated by serial passages in MRC- 5 cells was used. Since the 1970s, the investigational efforts on developing inactivated vaccine have been made. Inactivated by formaldehyde and tested on volunteers, this dead vaccine has been shown as efficient and safe [23]. In an experimental work with mice, a solid humoral and cellular immune response has been achieved by use of a deoxyribonucleic acid (DNA) vaccine. In order to get this vaccine, gene sequences encoding capsid and envelope glycoprotein E1 and E2 have been used [24].

\section{Prevention}

Vector control and individual protection from mosquitoes in the absence of active immunization represent major measures for prevention of chikungunya infection. A network of research laboratories capable of prompt diagnosing of arbovirus infections should be developed worldwide wherever Aedes albopictus exists in order to control chikungunya.

\section{Treatment}

Treatment of chikungunya is symptomatic. Bed rest, rehydratation and analgesics (among which ibuprofen, naproxen or acetaminophen are recommended) are needed. Acetylsalicylic acid should be avoided. Combination of alpha-interferon and ribavirin appears to have synergistic effect [25]. Chloroquine has successfully helped with chronic arthralgia caused by chikungunya virus, but has not been useful for acute arthralgia [4].

\section{Conclusion}

Considering expansion of chikungunya virus in the Caribbean and in South America, growing transportation, commercial and touristic connections of Serbian population and the presence of vector in the surrounding countries alerts to potential risk of chikungunya appearance in our country. 
Serbian health professionals must be educated on this arbovirus infection and its significance for public health. In addition, it may be useful to design programs for monitoring the vector and virus ac- tivities, on the basis of which a program of disease control and prevention should be created. This would be a multidisciplinary task for physicians, veterinarians, biologists and entomologists.

\section{References}

1. Brooks GF, Carroll KC, Butel JS, Morse SA, Mietzner TA. Jawetz Melnick Adelberg's. Medical Microbiology. 26th ed. New York: McGraw-Hill Lange; 2013.

2. Angelini R, Finarelli AC, Angelini P, Po C, Petropulacos $\mathrm{K}$, Silvi G, et al. Chikungunya in north-eastern Italy: a summing up of the outbreak. Euro Surveill. 2007;12(47):pii=3313. Available from: http://www.eurosurveillance.org/ViewArticle. aspx?ArticleId $=3313$

3. European Centre for Disease Prevention and Control (ECDC). Rapid Risk Assessment. Chikungunya outbreak in Caribbean region, 25 June 2014. [Internet]. Stockholm: ECDC; 2014. Available from: http://ecdc.europa.eu/en/publications/Publications/chikungunya-caribbean-june-2014-risk-assessment.pdf

4. Burt FJ, Rolph MS, Rulli NE, Mahalingam S, Heise MT. Chikungunya: a remering virus. Lancet. 2012;379(9816):662-71.

5. Paupy C, Kassa Kassa F, Caron M, Nkoghe' D, Leroy EM. A chikungunya outbreak associated with the vector aedes albopictus in remote villages of Gabon. Vector Borne Zoonotic Dis. 2012;12(2):167-9.

6. Kumar NP, Sabesan S, Krishnamoorthy K, Jambulingam P. Detection of Chikungunya virus in wild populations of aedes albopictus in Kerala State, India. Vector-Borne Zoonoic Dis. 2012;12 (10):907-11.

7. Depoortere E, Coulombier D, ECDC Chikungunya risk assessment group. Chikungunya risk assessment for Europe: recommendations for action. Euro Surveill. 2006;11(5):E06011.2.

8. Higgs S. Chikungunya virus: a major emerging threat. Vector Borne Zoonotic Dis. 2014;14(8):535-6.

9. Pialoux G, Gaüzere BA, Jaureguiberry S, Strobel M. Chikungunya, an epidemic arbovirosis. Lancet Infect Dis. 2007;7:319-27.

10. Ravi V. Re-emergence of cikungunya virus in India. Indian J Med Microbiol. 2006;24:83-4.

11. Cordel $\mathrm{H}$, the Investigation Group. Chikungunya outbreak on Réunion: update. Euro Surveill. 2006;11(3):E060302.3.

12. Noël H, Rizzo C. Spread of chikungunya from the Caribbean to mainland Central and South America: a greater risk of spillover in Europe? Euro Surveill. 2014;19(28):20855.

13. Charrel RN, De Lamballerie X, Raoult D. Seasonality of mosquitoes and chikungunya in Italy. Lancet Infect Dis 2008; 8(1):5-6.

Rad je primljen 3. X 2014.

Recenziran 26. XI 2014.

Prihvaćen za štampu 5. XII 2014.

BIBLID.0025-8105:(2015):LXVIII:3-4:122-125.
14. Gould EA, Gallian P, De Lamballerie X, Charrel RN. First cases of autochthonous dengue fever and chikungunya fever in France: from bad dream to reality! Clin Microbiol Infect. 2010;16(12):1702-4.

15. European Centre for Disease Prevention and Control. Epidemiological update: autochthonous cases of chikungunya fever in the Caribbean region and South America [Internet]. Available from: http:/www.ecdc.europa.eu/en/press/news/_layouts/forms/News DispForm.aspx? List $=8 \mathrm{db} 7286 \mathrm{c}-\mathrm{fe} 2 \mathrm{~d}-476 \mathrm{c}-9133-$ 18ff4cblb568\&ID=1018).

16. Popović N, Milošević B, Urošević A, Poluga J, Lavadinović L, Nedeljković J, et al. Outbreak of West Nile virus infection among humans in Serbia, August to October 2012. Euro Surveill. 2013;18(43):pii=20613.

17. Lam SK, Chua KB, Hooi PS. Chikungunya infection - an emerging disease in Malaysia. Southeast Asian J Trop Med Public Health. 2001;32:447-51

18. Fourie ED, Morrison JG. Rheumatoid arthritic syndrome after chikungunya fever. S Afr Med J. 1979;56:130-2.

19. Brighton SW, Prozesky OW, de la Harpe AL. Chikungunya virus infecton. A retrospective study of 107 cases. S Afr Med J. 1983:63:313-5

20. Kennedy AC, Fleming J, Solomon L. Chikungunya vira arthropathy: a clinical description. J Rheumatol. 1980;7:231-6.

21. Paquet C, Quatresous I, Solet JL, Sissoko D, Renault P, Pierre V, et al. Chikungunya outbreak in Réunion: epidemiology and surveillance, 2005 to early January 2006. Euro Survei11. 2006;11(2):E060202.3.

22. Panning M, Grywna K, van Esbroeck M, Emmerich P, Drosten C. Chikungunya fever in travelers returning to Europe from the Indian Ocean Region, 2006. Emerg Infect Dis. 2008 14:416-22.

23. Weaver SC, Osorio JE, Livengood JA, Chen R, Stinchcomb DT. Chikungunya virus and prospects for a vaccine. Expert Rev Vaccines. 2012;11(9):1087-101.

24. Muthumani K, Lankaraman KM, Laddy DJ, Sundaram SG, Chung CW, et al. Immunogenicity of novelconsensus-based DNA vaccines against Chikungunya virus Vaccine 2008;26:5128-34.

25. Briolant S, Garin D, Scaramizzino N, Jouan A, Crance JM. In vitro inhibition of Chikungunya and Semliki Forest viruses replication by antiviral compounds synergistic effect of interferonalpha and ribavirin combination. Antiviral Res. 2004;61:111-7. 